\title{
小幅パネルを引きボルト接合した CLT 壁の水平力に対する挙動 \\ LATERAL STRUCTURAL PERFORMANCE OF NARROW SIZE CROSS LAMINATED TIMBER CONNECTED WITH TENSILE BOLTS
}

\author{
弥浦壮太五十田 博**, 桘本敬大苂*, 中川貴 文***,

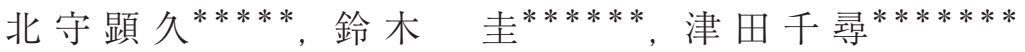 \\ Sota MIURA, Hirosi ISODA, Takahiro TSUCHIMOTO, \\ Takahumi NAKAGAWA, Akihisa KITAMORI, Kei SUZUKI \\ and Chihiro TSUDA
}

\begin{abstract}
Shear wall tests of single CLT wall of which size is 1x3m were conducted to evaluate the shear performance and $4 \mathrm{~m}$ width shear wall with opening tests consisting of double 1x3m of CLT panels and hanging panels were also conducted. Tensile bolts were used as connection between the shear wall and foundation, shear wall and hanging wall, and top-bottom of shear walls. Simple tensile tests for every bolt joint, compression, shear and bending tests for CLT panel were conducted to calculate the load-displacement relationship and to derive structural design procedure of the shear wall. As results of these static loading tests, the following conclusions are drawn;

1. Each CLT panel remained elastic and shear deformation of CLT panel is less than the connections deformation. This highlighted seismic performance of CLT construction is controlled by the design and detailing of the connections.

2. Equations to calculate load-displacement relationship of CLT shear walls are computed from the equilibrium of internal and external forces. The equations are validated with the experimental results.
\end{abstract}

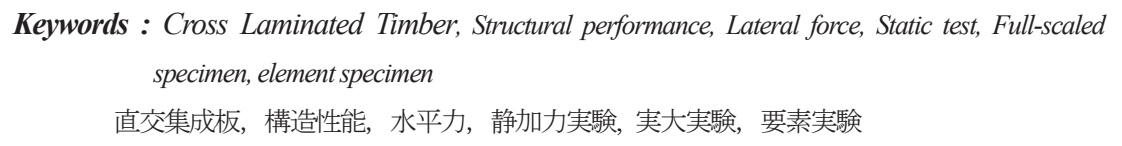

1. はじめに

クロス・ラミネイティド・ティンバー（Cross Laminated Timber、

以下 CLT と称する。）は、ひき板の各層を繊維方向が互いに直交す るように積層接着した板で、強度的に低質な材を内層部に利用でき、 かつ比較的高耐力を発現するため、木質構造における新たな建築用 材として注目されている。海外では、特に欧州を中心に近年利用が 急増し、水平構面として比較的大空間の構造で利用されるばかりで なく、6〜10 階建の中高層建物の壁床等にも利用されている。日本 では 2013 年 12 月に JAS（日本農林規格、直交積層板） ${ }^{1}$ )が制定され たが、いまだ基準強度は規定されておらず（2015 年 12 月末現在）、 建築確認では時刻歷応答解析による大臣認定が必要なため法的な八 ードルは高いが、いくつかの案件が新築、計画されている。そして、 今後、基準強度や仕様規定などの整備により、より一般的な方法で の安全、安心な建物の建設に期待がもたれているところである。
さて、このような CLT を用いた構造であるが、今のところ決まっ た構法は存在していない。材の大きさ、厚さの選択、床、壁の構成 方法、はり設置のありなし、はりを設置する場合の接合方法、垂れ 壁、腰壁の構成、材の勝ち負けなど、欧州のメーカーのカタログ例え ば2)や北米の CLT ハンドブック 3)などに書かれてはいるものの、仕様 規定的なルールが存在しているわけではない。接合強度なども例示 されてはいるが、結局のところ、一品生産的にケースバイケースで 機能性、安全性が計算や実験により担保されているのが現状である。 日本では現在のところ、材料、構成方法と部材強度や海外基準の 適用性の確認 4),5)など、日本独自の接合部 6)などなど、実験により強度 や変形性能についての把握がなされている段階で、構造のシステム としての検討はこれからである。

本研究ではそのような構造システムに関する研究、実建物の挙動 把握の第一歩として、5 層 5 プライで $1 \mathrm{~m}$ 幅の CLT を縦方向並びに
Grad. Stud., Graduate School of Engineering, Shinshu Univ.

Prof., RISH, Kyoto Univ./ Visiting Researcher, BRI, Dr.Eng.

Chief Research Eng., Dept. of Building Materials and Components,

Building Research Institute, Dr.Agr.

Senior Researcher, Building Dept., NILIM, MLIT, Dr.Agr.

Assist. Prof., Research Institute for Sustainable Humanosphere, Kyoto

Univ., Dr.Agr.

Chief Researcher, Wood Structure Prom/ The University of Tokyo,

M.Agr.

Structural Engineer, Team Architect Office, Dr.Eng. 
横方向にも引きボルト接合し、水平耐力に抵抗する壁構造について の検討を実施した。ラミナの樹種はスギ、内層のヤング係数の範囲 を $3.5 \sim 6.4 \times 10^{3} \mathrm{~N} / \mathrm{mm}^{2}$ 、最外層のそれを $5.0 \sim 7.9 \times 10^{3} \mathrm{~N} / \mathrm{mm}^{2}$ とした $\mathrm{JAS} の \mathrm{Mx} 60$ 相当が対象である。検討内容は、 $1 \mathrm{~m}$ 幅の無開口壁と $1 \mathrm{~m}$ 幅の無開口壁 2 枚と垂れ壁、腰壁などを組み合わせて $4 \mathrm{~m}$ 幅とし た壁の水平加力実験で各要素の試験結果から抵抗機構を明らかにす るとともに、荷重変形関係や強度の計算式などの提案を試みる、と いうものである。

\section{2. 想定している架構のイメージ}

本研究で対象としている架構を図 1 に示寸。接合詳細は文献7),8) 使用している金物の仕様は文献 9)を参照願いたい。ただし、実施時 期により多少の寸法等の違いがあるが、ここでは本論文で対象とす る構造のイメージとして理解いただきたい。壁はモジュール最小単 位小幅の CLT で、全面壁（以下、壁は全面壁を指す）の上下端と垂 れ壁部分で引きボルト接合されている。垂れ壁の引きボルトは壁の 上下方向の接合と垂れ壁の水平方向部分の接合が互いに交差するた め、壁の接合を優先し、垂れ壁は上下各々ボルト 2 本で接合してい る。この引きボルトにより曲げモーメントを伝達する。せん断力は 壁下端の中央部分を $\mathrm{U}$ 型金物、上端を $\mathrm{L}$ 形金物で、垂れ壁端部の中 央部分を平型金物の鋼板添え板でビス接合し、伝達している。腰壁 がある場合には引きボルトは付けず、外れない程度に長さ $185 \mathrm{~mm}$ のビス 5 本を用いて壁と腰壁を斜め打ちしている。なお、壁、腰壁、 垂れ壁と区別しない場合にパネルと称する。

\section{3、1P壁の性能}

\section{1 壁の実験と弾性時のカの釣り合い式の誘導}

幅 $1 \mathrm{~m}$ で高さ $3 \mathrm{~m}$ の無開口壁（以下、1P 壁）に対して面内せん断 実験を実施した。試験体は図 1 に示した壁に対し、2.で説明した 引きボルトを用いて脚部を基礎に相当する部分に接合するもので、 土台などを敷かず直接接合することを想定した試験体と床があるこ とを想定した試験体の 2 種類である。床には 5 層 5 プライの CLTを 用いた。試験体詳細は文献 ${ }^{10)}$ を参照願いたい。試験方法は壁倍率や

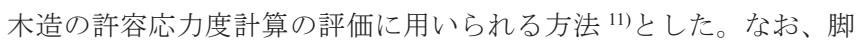
部のせん断力を伝えるU 型金物がモーメント抵抗するのを防ぐため、 ここではこれを設置せず、 $\phi 50$ のせん断キーを CLT と鋼材、ある いは木床との間に挿入し、せん断力に抵抗させた。

実験結果のせん断力と変形角の関係を図 2 に示寸。終局状態はい ずれも後述する図 5 の右図のように引きボルト部分のせん断破壊で あった。床のないものは 3 体のうち 2 体が塑性化せずに脆性的な挙 動をし、1 体でのみ明確な塑性化がみられた。床のある試験体では すべてで塑性化後、引きボルト部のせん断破壊が生じ荷重低下した。

このような抵抗機構を力学モデルで表現するため、まず、床のな い試験体では脚部の抵抗挙動を鉄筋コンクリート造の単筋ばりと同 様と考え、力と変形の釣り合い式をたて、せん断力と各部応力の関 係を得ることとした。以下にその流れを示す。式中の変数などにつ いては図 3 を参照願いたい。

単筋ばりにおいて圧縮縁から中立軸までの距離 $x$ は式(1)の 2 次方 程式を解くことにより、曲げモーメント $M$ と縁応力 $\sigma_{\mathrm{C}}$ 、引張力 $T$ と の関係は CLT 壁の脚部において、式(2)で与えられる。

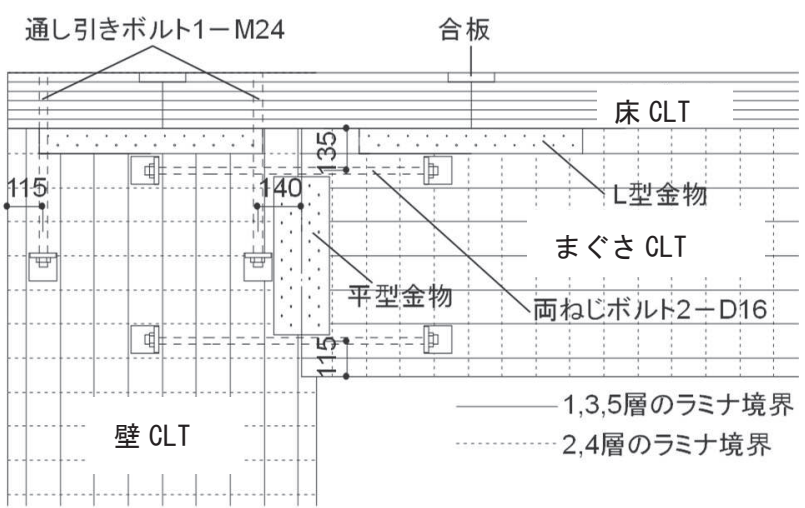

引きボルト1ーM24

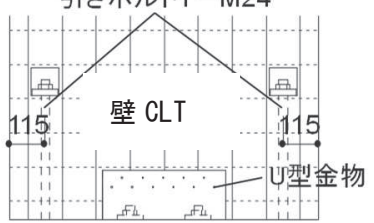

図 1 架構のイメージと詳細図

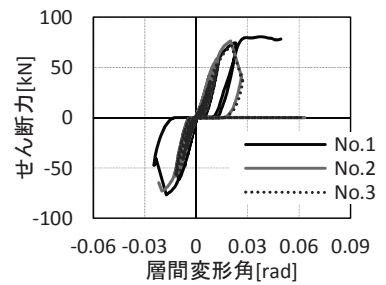

(a) 床なし試験体

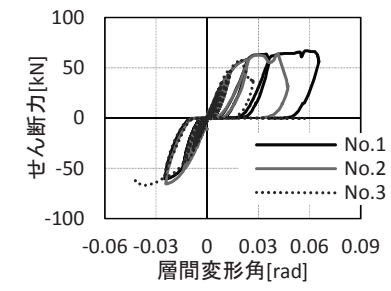

（b）床あり試験体
図 $21 \mathrm{P}$ 壁実験・せん断力変形角関係

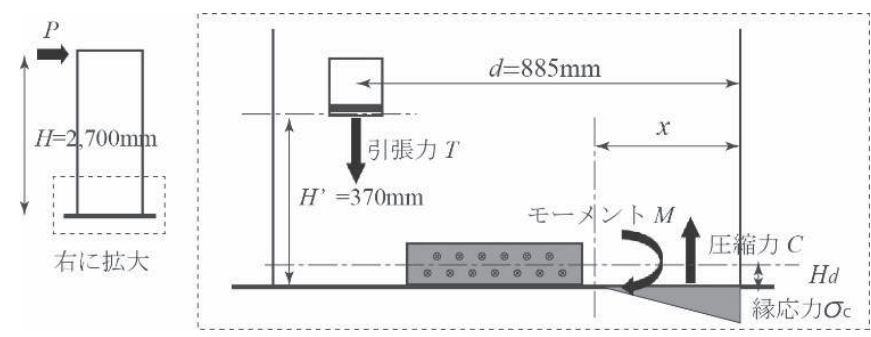

図 3 モーメント分布のイメージ（拡大図）

$\frac{1}{2} b x^{2}+a_{t} n x-a_{t} n d=0$

$M=\frac{1}{2} \sigma_{c} b x\left(d-\frac{1}{3} x\right)=T\left(d-\frac{1}{3} x\right)$

$b$ : 壁 CLT の厚さ、 $a_{t}$ : 引きボルトの有効断面積、 $n:=E_{t} / E_{c}$ 、 $E_{t}$ : 引きボルトの見かけのヤング係数、 $E_{c}$ : 壁 CLT の圧縮側の 見かけのヤング係数、 $d:$ 圧縮縁から引張側の引きボルトまで の距離

ここでヤング係数を見かけとしているのは、引張側は引きボルト を含む引張要素実験で得られた剛性 $k$ に基づいてヤング係数を式(3) により求めることにより、圧縮側は壁 CLT を構成するラミナの繊維 方向を考慮し、繊維平行方向と繊維直角方向の並列バネと考えて式 (4)により求めることによる。 


$$
E_{t}=\frac{k l}{a_{t}}
$$

$l$ : ボルトの締め付け間距離 (図 3 の $H^{\prime}$ に座金等の厚さを加算)

$E_{c}=\frac{E_{/ /} A_{/ /}+E_{\perp} A_{\perp}}{A_{/ /}+A_{\perp}}$

$E_{/ /}$: ラミナ繊維平行方向のヤング係数、 $E_{\perp}:$ ラミナ繊維直角方 向のヤング係数、 $A_{/ /}$: ラミナ瀻維平行方向の断面積、 $A_{\perp}:$ ラミ ナ繊維直角方向の断面積

回転剛性Rはモーメントを回転角で割った值で式(5)となる。

$$
R=k(d-x)\left(d-\frac{1}{3} x\right)
$$

脚部接合部に生じる $M$ は、せん断力 $P$ と、その作用点とせん断抵 抗する距離から求まり、式(6)で表される。

$$
\begin{aligned}
& M=P\left(H-H_{d}\right) \\
& H: \text { 加力点から CLT 壁下端までの距離 } \\
& H_{d}: \text { CLT 壁下端からせん断力抵抗までの距離 }
\end{aligned}
$$

壁の変形は式(5)で求められる脚部回転角に高さを乗じ、壁自体の 曲げ変形 $\delta_{b}$ とせん断変形 $\delta_{s}$ を加えることにより求められる。曲げ変 形は曲げヤング係数と圧縮ヤング係数が等しいとして式(7)により、 せん断変形は全層のラミナが有効と考え式(8)により求めた。ここで、

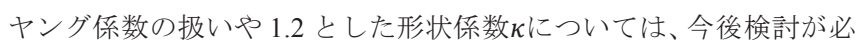
要と考えている。

$$
\begin{aligned}
& \delta_{b}=\frac{P\left(H-H_{d}\right)^{3}}{3 E_{c} I} \\
& I: \text { 壁の断面二次モーメント } \\
& \delta_{s}=\frac{P\left(H-H_{d}\right)}{G A / \kappa}
\end{aligned}
$$

$A$ : 全断面積、 $G$ : せん断弾性係数、 $\kappa=1.2$

次に、床のある試験体の荷重変形は、木質構造接合部設計マニュ アルの引きボルト式柱一梁接合部 ${ }^{12}$ に倣い求めることとした。こち らも、前述と同様に力と変形の釣合い条件により導かれている。算 出における各係数等の詳細を付録 1 に示した。引きボルト式柱一梁 接合部では、引張側の剛性を引きボルト、座金部分のめり込みなど により求めているが、ここでは実験結果を用いた。水平力や変形な どが式(6)〜(8)によって求められる点は床なしと同様である。

\section{2 要素実験による各パラメータの設定}

引きボルトの要素実験 ${ }^{13)}$,14) 本研究で用いた接合部と同様の 接合位置において実施した引張実験の結果を図 4 に示す。また、同 図中にはバイリニアとトリリニアに置換したモデルも併記した。な お、主な終局状態は図 5 に示すような局部的なせん断と引張断面の 破断であった。

CLT の面内部分压縮実験 CLT の面内部分圧縮実験について は既往の研究が少なく、パラメータをふって、実験的にその挙動を 明らかにすることとした。試験体を図 6 に示す。部分圧縮である端
部圧縮、中間部圧縮に加え、全面圧縮も併せて実施した。図は材せ い $200 \mathrm{~mm}$ であるが、端部圧縮と全面圧縮では $100 \mathrm{~mm} 、 300 \mathrm{~mm}$ のも のについても実施し、各種類 6 体の合計 42 体である。本試験は壁実 験を実施した健全部分を横方向に切断し、製作した、つまり、加力 方向に対して表層と 3 層が繊維平行方向で、2 層と 4 層が繊維直角 方向である。試験は試験体下部全体を平滑な反力床で支持し、加力 板により圧縮力を加えた。変位は底板と加力板の間を測定した。

典型的な荷重変形関係を図 7 に示す。いずれの試験体も挙動は似 通っており、直線的な荷重上昇の後、最大荷重に至り、その後徐々 に荷重低下寸るというものであった。実験結果を整理して表 1 に示 した。各試験体とも 6 体の平均值である。なお、見かけのヤング係 数は安定した弾性挙動として、最大荷重の $0.2 \sim 0.5$ 倍の区画を評価 の対象とした。結果を考察すると、圧縮強度は部分圧縮と全面圧縮 の比較では部分圧縮が大きく、特に中間部圧縮の值が大きく繊維直 交方向のめり込みによる耐力上昇がみてとれる。見かけのヤング係 数は中間部圧縮が高いものの、端部圧縮と全面圧縮ではその違いが

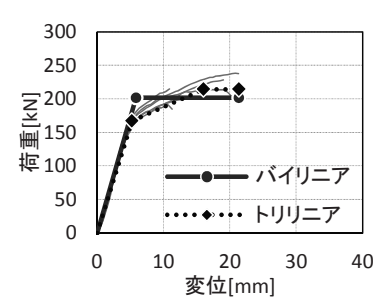

図 4 引きボルトの要素実験

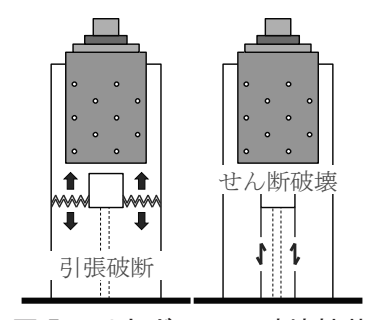

図 5 引きボルトの破壊性状

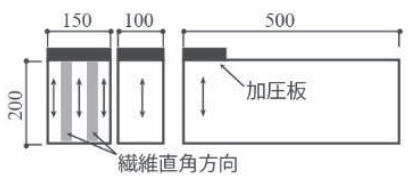

(a) 全面

(b) 端部

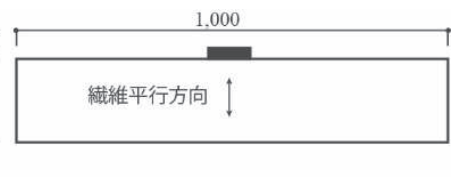

(c) 中間部
図 6 部分圧縮実験・試験体図一例（材厚 $200 \mathrm{~mm}$ ）

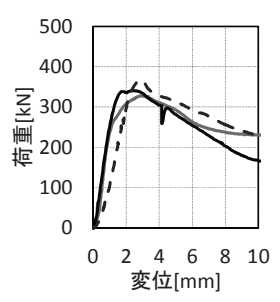

(a) 全面

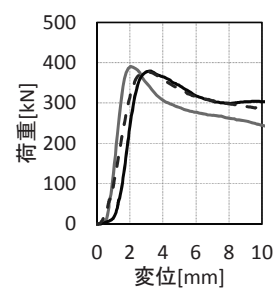

(b) 端部

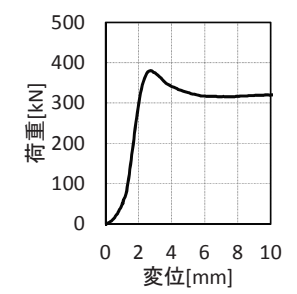

(c) 中間部
図 7 部分圧縮実験・典型的な荷重変位関係

表 1 部分圧縮実験 · 実験結果（カッコ内は変動係数）

\begin{tabular}{c|c|c|c|c}
\hline $\begin{array}{c}\text { 材厚 } \\
{[\mathrm{mm}]}\end{array}$ & $\begin{array}{c}\text { 圧縮 } \\
\text { 部分 }\end{array}$ & $\begin{array}{c}\sigma_{\max } \\
{\left[\mathrm{N} / \mathrm{mm}^{2}\right]}\end{array}$ & $\begin{array}{c}\sigma_{\mathrm{y}} \\
{\left[\mathrm{N} / \mathrm{mm}^{2}\right]}\end{array}$ & $\begin{array}{c}E_{\mathrm{c}} \\
{\left[\mathrm{N} / \mathrm{mm}^{2}\right]}\end{array}$ \\
\hline \multirow{2}{*}{100} & 全面 & $23.3(5.4)$ & $19.4(3.8)$ & $2,109(9.0)$ \\
\cline { 2 - 5 } & 端部 & $25.6(2.3)$ & $24.1(7.3)$ & $2,563(9.2)$ \\
\hline \multirow{2}{*}{200} & 全面 & $23.9(4.6)$ & $22.4(7.3)$ & $4,109(8.6)$ \\
\cline { 2 - 5 } & 端部 & $25.5(5.5)$ & $23.4(4.5)$ & $3,984(12.9)$ \\
\cline { 2 - 5 } & 中間部 & $27.2(3.5)$ & $26.1(4.1)$ & $4,810(14.2)$ \\
\hline \multirow{2}{*}{300} & 全面 & $23.6(4.2)$ & $21.2(6.0)$ & $4,050(9.3)$ \\
\cline { 2 - 5 } & 端部 & $25.6(2.9)$ & $23.1(8.1)$ & $4,591(12.0)$ \\
\hline
\end{tabular}


明確にはみられない。厚さ $100 \mathrm{~mm}$ の見かけのヤング係数の值が小 さいのは、加力板近傍で生じた局部的な繊維圧縮の影響と考えられ る。以降の計算では $200 \mathrm{~mm}$ の平均值をヤング係数として用いる。 CLT の面内せん断実験面内部分圧縮実験同様、CLT の面内せ ん断実験についても実験的に性能を確認した。実験方法は逆対称 4 点荷重法により、同じ試験体について 6 体を実施した。試験体の大 きさは、せいが $240 \mathrm{~mm}$ 、荷重区間も同じく $240 \mathrm{~mm}$ である。表 2 に 結果を示した。これよりせん断弾性係数 $\mathrm{G}$ を求めた。参考までに本 実験で得られたせん断強度 $\tau$ も示した。

\section{3 非線形への拡張と降伏モード}

非線形挙動を呈する部分は引きボルト接合部、CLT 壁の圧縮側、 そして床のある試験体では床へのめり込みと考えた。その非線形挙 動を解析的に求めるにあたり、区分線形化増分解析を用いた。具体 的に床なしの試験体を例に説明すると、初期の剛性に対して式(1) を適用し中立軸を求め、降伏荷重に対して式(2)を適用し、圧縮側で 降伏か引張側の降伏かの判定を実施し、どちらか小さい方の值で降 伏するとして降伏モーメントを求める。ついで降伏した要素に関し ては剛性を入れ替え式(1)で再度中立軸を計算し、次の降伏判定をお こなう。この手順を繰り返す、というものである。

ここで、実験時の降伏状態について確認しておく。図 8 は $1 \mathrm{P}$ 壁 実験の壁脚部の引きボルトの軸力と浮き上がり関係を要素実験に基 づいて定義したトリリニアモデルと重ねて示したものである。床の 有無に関わらず、引きボルトは降伏、終局に達している。ついで、 壁 CLT 脚部の圧縮降伏について確認寸る。図 9 に床のない試験体に おける壁の圧縮側の挙動として、横軸を層間変形角とし、縦軸は三 角変位めり込みと仮定して式(9)により算出した圧縮応力度 $\sigma_{c}$ を示 した。図中には表 1 で示した端部圧縮での降伏応力度 $\sigma_{\mathrm{y}}$ の平均值も 示してある。圧縮側では 1 体が降伏に至っていることがわかる。こ の試験体は、勒性が高かった試験体であり、床なし試験体の勒性は 壁 CLT の圧縮側の局部的な塑性化が関連している。一方、床あり試 験体の床は写真 1 のようにめり込みによる残留変形がみられ、塑性 化が進んだことが容易にわかる。

$$
\begin{aligned}
& \sigma_{c}=\frac{N}{x \times b} \times 2 \\
& N: \text { 浮き上がり側軸力 }(=T) 、 b: \text { CLT の幅 }
\end{aligned}
$$

さて、図 10 には実験結果と区分線形化増分解析の結果を示した。 ここで、式(6)などで用いられている $H_{d}$ はゼロとした。この仮定に ついては後述する。やや最大荷重を小さ目に計算しているものの、 降伏荷重、降伏変位を良好に追跡できていることがわかる。

ここで、 $H_{d}$ の仮定について、いくつかの検討結果を述べる。図 11 は、中立軸の距離 $x$ を実験時に壁の両端に設置した変位計より変位 ゼロの点として求め、計算結果と比較したものである。実験結果は 横軸を層間変形角とし、壁の荷重変形をバイリニアモデルに置換し た際の降伏点 $\theta_{v}$ も重礼て示した。初期剛性により求めた計算による 中立軸は、床なしで $257.8 \mathrm{~mm}$ 、床ありで $392.9 \mathrm{~mm}$ であった。降伏点 での直接的な比較はできないが、床なし試験体では押し引きの中間 的な值であり中立軸は実験と計算で一致している。終局状態では実 験結果が計算結果に漸近しており、追跡できている。床ありは、降
伏点ではやや計算值が小さ目であるが、ほぼ妥当、終局状態では計 算值がやや小さ目の結果を与えている。

表 2 せん断剛性・せん断強さ

\begin{tabular}{c|c|c|c}
\hline \multicolumn{2}{c|}{ せん断弾性係数 $\mathrm{G}$} & \multicolumn{2}{|c}{ せん断強度 $\tau$} \\
\hline 平均 & 変動係数 & 平均 & 変動係数 \\
\hline $791.9 \mathrm{~N} / \mathrm{mm}^{2}$ & $16 \%$ & $4.18 \mathrm{~N} / \mathrm{mm}^{2}$ & $4.6 \%$ \\
\hline
\end{tabular}

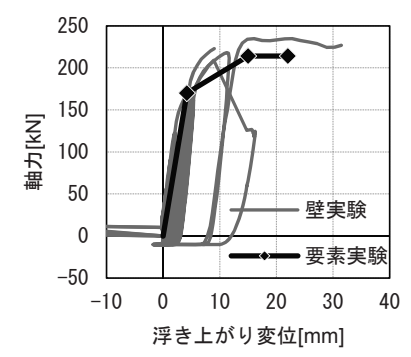

（a）床なし試験体

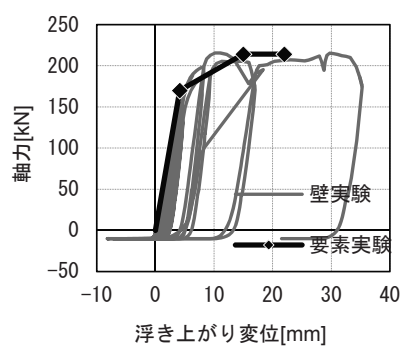

（b）床あり試験体
図 $8 \quad 1 \mathrm{P}$ 壁実験・浮き上がり側挙動

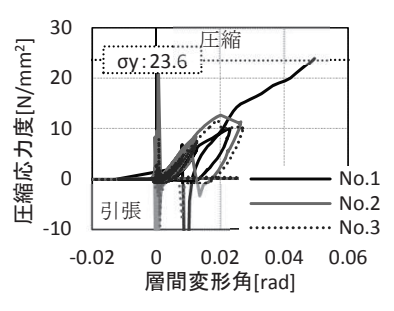

図 9 圧縮側挙動（床なし）

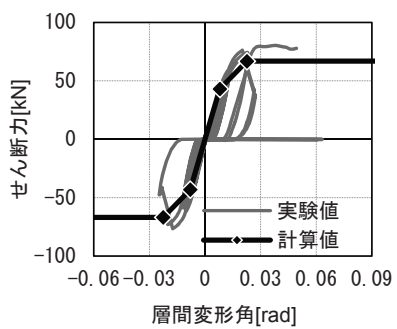

(a) 床なし試験体

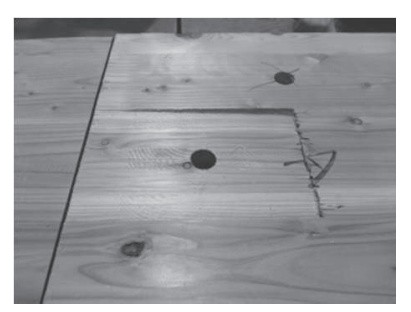

写真 1 床へのめり込み降伏

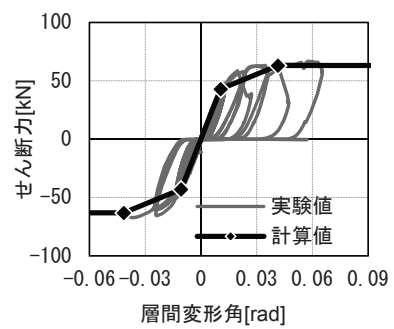

（b）床あり試験体
図 10 非線形挙動解析結果

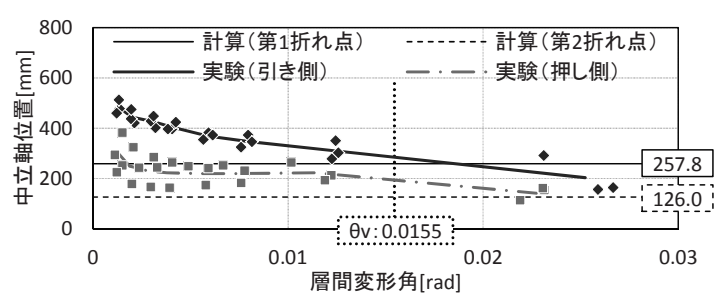

(a) 床なし試験体

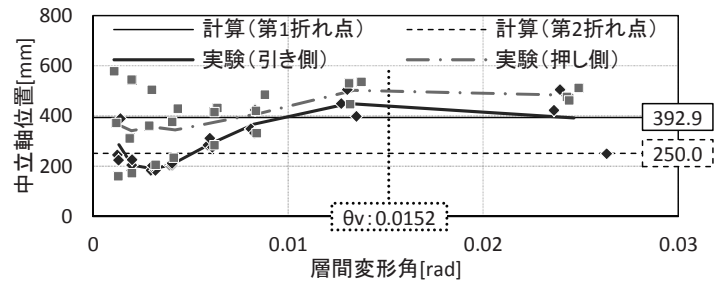

(b) 床あり試験体

図 $111 \mathrm{P}$ 壁実験・圧縮縁から中立軸までの距離 
ついで、引きボルトに設置したロードセルから得られた引き抜き 力で、壁高さ $H$ と水平力を乗じ求めたモーメントを除して、式 (2) 中の $(d-1 / 3 x)$ を求め、それより中立軸 $x$ を求め比較を試みた。そ の結果、 $x$ は終局状態ではほぼゼロあるいはマイナスの值となった。 この原因として、 $H_{d}$ がゼロではないこと、あるいはせん断抵抗に用 いたドリフトピンが引き抜ける際に摩擦力が生じて、曲げ抵抗して いること、などが考えられる。また、引きボルトがせん断抵抗して おり、そのせん断の抵抗位置によって $H_{d}$ が影響を受けていることが 考えられる。仮に逆算的に実験結果を再現できる $H_{d}$ を求めると、壁 脚部から引きボルトの座金下端までの距離の中央にあり、 $H_{d}=1 / 2 H^{\prime}$ であった。なお、この部分での抵抗挙動は曲げ抵抗に加えて、図 12 に示すように、圧縮ストラットが形成され抵抗していると考えられ る。今回の実験方法では $H_{d}=0$ として計算するほうが理論整合して いると考えられるが、不明の抵抗要素もあり、今後検討を要すると 考えている。なお、設計上は $H_{d}=0$ で安全側の仮定となることを念 のため申し添える。

以上、多少課題があるものの力の釣り合いで $1 \mathrm{P}$ 壁の耐力をほぼ 追跡できることを確認した。ここで、釣り合い鉄筋比以下の鉄筋コ ンクリート梁の曲げモーメント計算式と同じ構成とした場合、降伏 モーメントと終局モーメントを求める式と係数を式(2)と図 11 の結 果を参考に整理すると、式(10)となる。なお、引きボルトの形が異 なる、CLT壁の厚さが異なるといった場合には、式(1)に立ち返って 整理すればよい。さらに引張接合や圧縮塑性に関するパラメータス タディにより、設計時のより適切な係数が提案できると考えている。

$$
\begin{aligned}
& M=T \times j \\
& \text { 床なし } \\
& \text { 床あり } \quad M_{a}: j=0.90 \times d \quad M_{u}: j=0.85 \times d \quad M_{u}: j=0.95 \times d \\
& d: \text { 引張側ボルトから圧縮縁までの距離 }
\end{aligned}
$$

\section{4. 構面の実験と接合部実験との関係}

\section{1 構面実験}

実験概要 試験体は図 1 に示した接合を用いた、壁・まぐさ・ 床・腰壁パネルからなる 1.5 層の構成とし、腰壁を設けた試験体 (以 下、腰壁あり） 1 体と腰壁のない試験体（以下、腰壁なし） 3 体とし

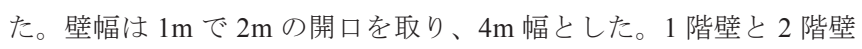
の間に床を設け、 2 階床 CLT は厚さ $180 \mathrm{~mm}$ の 5 層 6 プライである。

図 1 について材料も含めもう少し詳しく述べると、引きボルトは基 礎一壁間および壁－壁間は M24 両ネジボルト（SCM435）とし、座 金はそれぞれ厚さ $19 \mathrm{~mm} 、 25 \mathrm{~mm}$ を用いた。まぐさ一壁間は 2-M16 両ネジボルト（SNB7）で厚さ $16 \mathrm{~mm}$ の座金を用いた。引きボルトは 手締め後スパナで $1 / 4$ 回転に管理した。また、基礎一壁間に U 型の 金物、壁一床間に $\mathrm{L}$ 型の金物、まぐさ一壁間に平型の金物を用い、 長さ $65 \mathrm{~mm}$ のビスを用いて、基礎一壁間は両面で 22 本、壁一床間 では片側 22 本、まぐさ一壁間では片面にのみ 32 本で留めつけた。 これらのビスの本数は、事前の実験などでせん断力に対して抵抗で きるように設計した結果である。また、腰壁一壁間は引きボルトを 用いず、長さ $185 \mathrm{~mm}$ のビス 5 本を斜め打ちして接合したのみであ る。床は壁の長さ方向に直交して配されることを想定し、両端を $500 \mathrm{~mm}$ 幅として、間に $1 \mathrm{~m}$ の床を長さ $500 \mathrm{~mm}$ として挿入した。床 CLT 同士は、厚さ $24 \mathrm{~mm}$ 、幅 $150 \mathrm{~mm}$ の構造用合板をスプライン材

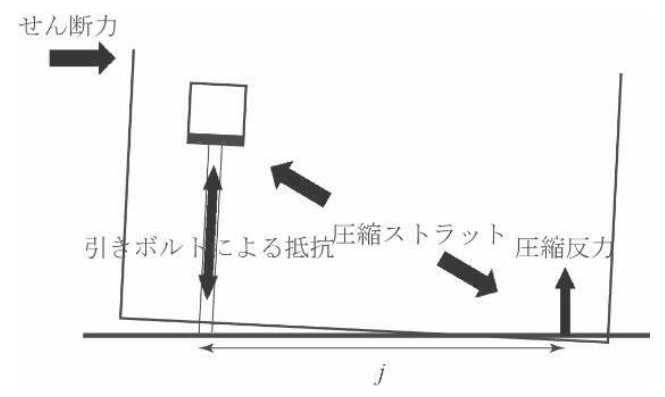

図 12 脚部の抵抗機構（アーチ機構）

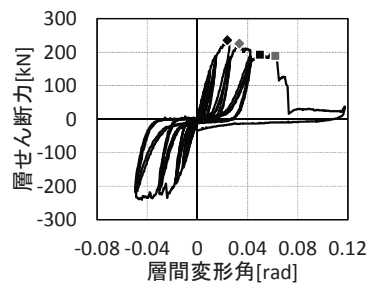

(a) 腰壁あり

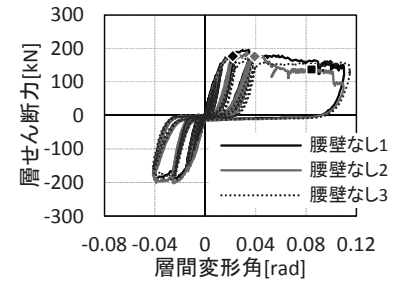

(b) 腰壁なし
図 13 構面実験の 1 層層せん断カー層間変形角関係

: : 最大荷重点、 最大荷重の 8 割に低下した点

表 3 構面実験 · 実験結果

\begin{tabular}{c|c|c|c|c|c|c}
\hline & $\begin{array}{c}Q_{\max } \\
{[\mathrm{kN}]}\end{array}$ & $\begin{array}{c}\theta_{Q \max } \\
{[\mathrm{rad}]}\end{array}$ & $\begin{array}{c}Q_{\mathrm{y}} \\
{[\mathrm{kN}]}\end{array}$ & $\begin{array}{c}Q_{u} \\
{[\mathrm{kN}]}\end{array}$ & $\begin{array}{c}K \\
{[\mathrm{kN} / \mathrm{rad}]}\end{array}$ & $D s$ \\
\hline 腰壁あり & 235 & 0.024 & 173 & 200 & 14,760 & 0.325 \\
\hline 腰壁なし 1 & 195 & 0.035 & 153 & 177 & 14,203 & 0.373 \\
\hline 腰壁なし 2 & 187 & 0.033 & 149 & 169 & 12,722 & 0.323 \\
\hline 腰壁なし 3 & 176 & 0.036 & 133 & 157 & 12,545 & 0.355 \\
\hline 平均(なし) & 186 & 0.035 & 145 & 168 & 13,156 & 0.351 \\
\hline あり/なし & 1.3 & 0.7 & 1.2 & 1.2 & 1.1 & 0.9 \\
\hline
\end{tabular}

として用い接合した。詳しくは文献7),8)を参照願いたい。

1 層高さは $3,000 \mathrm{~mm}$ とし、加力は 1.5 層の位置で両端の CLT 壁の 中央をピン接合したうえで、それを押し引きした。加力方法はみか けのせん断変形角で制御し、正負交番 3 回繰り返し加力とした。目 標変形角は加力点高さでの変形角が 1/450、1/300、1/200、1/150、1/100、

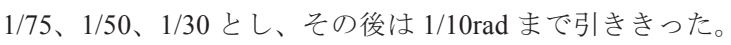

実験結果図13 亿各試験体の1層の層せん断力一層間変形角関 係を示す。表 3 に実験結果として最大層せん断力 $Q_{\max }$ とその時の変 形角 $\theta_{Q \max }$ 降伏層せん断力 $Q_{y}$ 、終局層せん断耐力 $Q_{u}$ 、初期岡性 $K$ 、 構造特性係数 $D s$ をまとめて示した。これらは耐力壁の評価法と同 様 ${ }^{11)}$ にバイリニア置換して求めた。表中には腰壁ありと腰壁なしの 比も示したが、腰壁なしについては 3 体の平均值とした。腰壁によ る壁 CLT の回転拘束により、初期剛性、最大層せん断力共に腰壁あ りの方が腰壁なしより高い值を示し、初期剛性で 1.1 倍、最大層せ ん断力で 1.3 倍を示した。1P 耐力壁は $76.1 \mathrm{kN}$ の最大せん断耐力で あった。無開口壁が 2 枚あり、腰壁がある場合には無開口壁分の 1.5 倍、腰壁のない場合には 1.2 倍と計算された。1P 壁が片持ち梁形式 であったのに対して、腰壁や垂れ壁部分でモーメント負担したこと により反曲点位置が下がり、せん断抵抗力が上昇したものと考えら れる。また、構造特性係数 Ds は 0.32 程度で $1 \mathrm{P}$ 壁の床のない試験体 では勒性がなく、小幅の CLT を組み合わせることにより、勒性が高 くなった。 
ここで、各試験体の主な破壊性状について考察すると、いずれの 試験体においても主な破壊性状は、1 層脚部接合部の引つ張り破壊 と、まぐさ一壁接合部のボルトの降伏あるいは破断であった。接合 部で CLT パネルにめり込みが生じたが、CLT 壁自体がせん断破壊す ることはなかったことから、接合部の性能が CLT 構面の保有水平耐 力を決める要因であるといえる。接合部の変形モードをもう少し詳 しく検討するため、図 14 に最大層せん断力到達時の変形図を示した。 腰壁なしでは最大層せん断力、降伏層せん断力などで最も平均的な

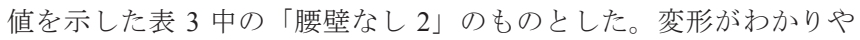
すいように、実験值に対して変位を 5 倍拡大してある。基礎一壁間 で引張力を負担している箇所（図中、(1)(2)）とまぐさ一壁間で引張 力を負担している箇所（図中、(3)(4)）の軸力ー層間変形角関係を図 15 に示す。なお、図 13 中の点と接合部の点が対応している。まず、 基礎一壁間の引きボルトが最大引っ張り力に達した時点で、この接 合部は脆性的に荷重が低下寸る。しかしこの時点でまぐさ一壁間の 引きボルトは最大ではなくまだ余裕がある。そこで、まぐさ一壁間 のモーメント負担が多くなり、さらに、まぐさ一壁間の勒性によっ て壁の勒性が確保される。その後まぐさ一壁間の破壊によって、層 の荷重変形において荷重低下が生じる。以上が各接合部の挙動分析 である。なお、1/10radまでに壁脚部の引きボルト部の破壊が生じた。

\section{2 増分解析による実験結果の追跡}

すべてのパネルをブレース置換し、各接合部の実験結果をモデル 化した非線形バネとして表現し、増分解析を実施した。ここでパネ ルのブレース置換のブレース断面は面内せん断実験より定義した。 非線形要素は壁端部に設置した引きボルト、圧縮は面内部分圧縮実 験より定義した圧縮要素、並びにめり込み要素、さらにパネル間の 端部中央部に設置したせん断抵抗と回転抵抗用のビスの要素である。 なお、せん断抵抗用のビスについてもその挙動を実験的に求めた。 また、脚部のせん断金物の回転抵抗については、後述する鋼板の曲 げにより剛性、耐力を決定した。解析結果と実験結果を比較し図 16 に示す。増分解析により良好に実験結果を再現できることがわかる。

\section{3 引きボルト接合部の性能から構面の終局耐力の推定}

ここでは節点振り分け法により構面の終局せん断耐力の推定を試 みる。図 17 に示すようなモーメント図を想定し、式(11)により終局 層せん断力 $Q_{u}$ を求める。

$$
Q_{u}=\frac{M_{1 t}+M_{1 b}}{H_{1}} \times 2
$$

1 層頭部モーメントは、式(12)の通りにまぐさ端部モーメント $M_{1 h}$ から 2 層脚部モーメント $M_{2 b}$ を引くことにより求まり、2 層脚部モー メントは終局層せん断力 $Q_{u}$ から式(13)により求まる。

$$
\begin{aligned}
& M_{1 t}=M_{1 h}-M_{2 b} \\
& M_{2 b}=\frac{1}{2} Q_{u} \cdot H_{2}
\end{aligned}
$$

ここでの釣合いは材軸中心位置であり、2 階脚部は脚部せん断金 物の位置で降伏が生じていないことを確認した上で、以上を整理す ると、式(14)が得られる。

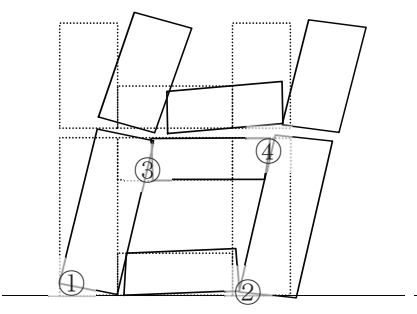

(a) 腰壁あり

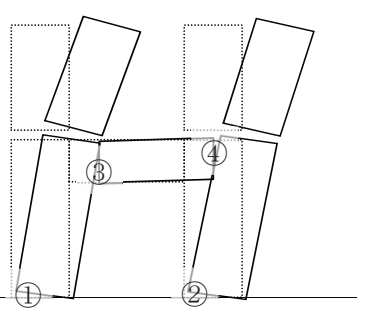

（b）腰壁なし
図 14 構面実験 - 最大層せん断力時の変形図

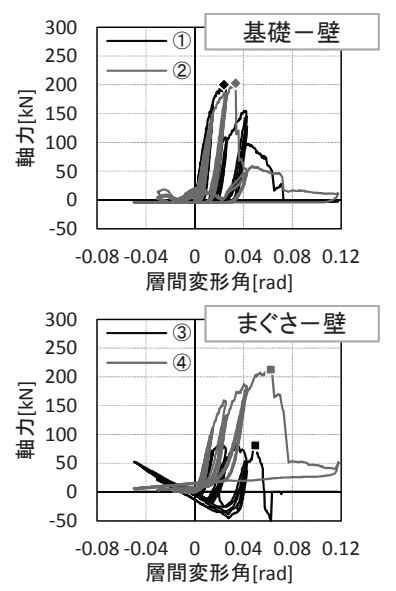

（a）腰壁あり
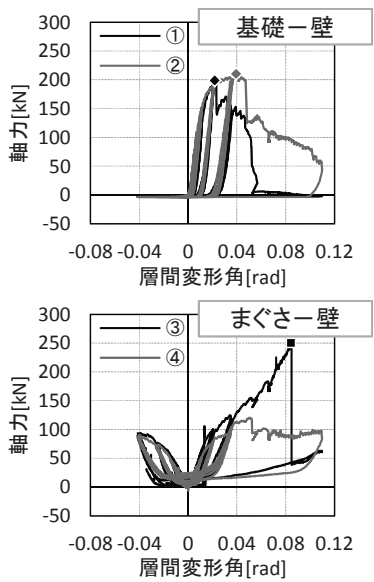

（b）腰壁なし
図 15 構面実験・接合部の軸力層間変形角関係

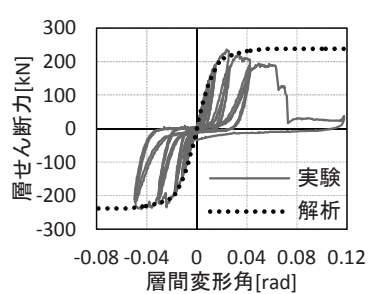

（a）腰壁あり

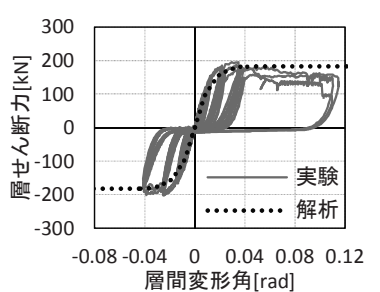

（b）腰壁なし
図 16 増分解析と実験結果の比較

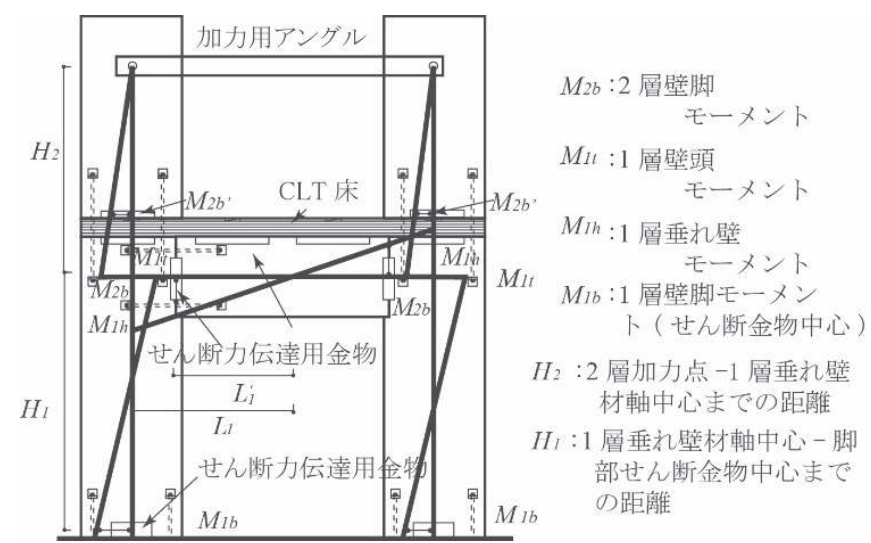

図 17 構面実験・想定するモーメント図

$$
Q_{u}=\frac{M_{1 h}+M_{1 b}}{H_{1}+H_{2}} \times 2
$$

ここで垂れ壁のせん断力伝達位置のモーメント $M^{\prime}{ }^{\prime}$ と材軸中心位 
置でのモーメント $M_{1 b}$ での換算は以下となる。

$$
M_{1 b}=\frac{L_{1}}{L_{1}^{\prime}} M_{1 b}^{\prime}
$$

同様に 2 階脚部も引きボルト位置で置換して求めた。計算は、抵 抗要素やその算定方法を変え 3 ケースについて実施した。ケース 1 は、脚部、まぐさ端部共に引きボルトのモーメント抵抗のみとし、 要素実験で得られた引きボルトの終局耐力から算出したものである。 ケース 2 はせん断金物によるモーメント抵抗も考慮したものである。 せん断金物で発生するモーメント抵抗は、壁の終局層間変形角 $\theta_{u}$ の 時のビス 1 本毎の浮き上がり変位 $\delta_{i}$ を回転中心からのそれぞれのビ スの距離に変形角を乗じることにより求め、図 18 に示すビス打ちせ ん断金物の要素実験により求めたビス 1 本あたりの耐力のバイリニ ア特性に基づき式(16)、(17)により求めた。

$$
\begin{array}{ll}
M_{s}=\sum L_{i} \cdot\left(P_{u} \times \frac{\delta_{i}}{\delta_{v}}\right) & \delta_{v}>\delta_{i} \\
M_{s}=\sum L_{i} \cdot P_{u} & \delta_{v}<\delta_{i}
\end{array}
$$

$L_{i}$ : 各ビスと CLT 壁脚部の圧縮側を三角形部分とした合力ま での距離

1 層脚部については、実験で金物の曲げ変形によるものが先行し た。そこで、図 19 のように中央のボルト位置で支持された片持ちば りとし、式(18)により計算し加算した。

$$
M_{s}=2 P \cdot L_{s}=2 \cdot \frac{\frac{b h_{s}{ }^{2}}{6} \cdot \sigma_{y}}{l} \cdot L_{s}
$$

$b: \mathrm{U}$ 型せん断金物の幅、 $h_{s}: \mathrm{U}$ 型せん断金物の板厚、 $\sigma_{y}:$ 鋼 材の降伏曲げ応力度、 $l$ : ボル卜位置から CLT 表面までの距 離、 $L_{s}: \mathrm{U}$ 形せん断金物の中心から CLT 壁脚部の圧縮側を三 角形部分とした合力までの距離

ケース 3 は脚部が終局耐力を迎えた時点であっても、まぐさ端部 が終局には至っていないので、その影響を考慮したものである。具 体的には、1 層脚部引きボルトが降伏変位 $\delta_{v}$ に達した時点でのまぐ さの曲げ抵抗を、まぐさ上下端に設置した変位計よりボルトの引張 力と回転角に基づいて算出した。また、引きボルトに乗じるjは 1 層 脚部を $0.95 d$ と、まぐさでは $0.90 d$ とした。1 層脚部引つ張り耐力 は、図 4 で示したバイリニアの終局耐力とした。まぐさ端部におい てもこれと共に実施された要素実験により決定するが、壁側の固定 とまぐさ側の固定があるので、それを直列バネとして剛性を求め、 終局耐力は小さい方の值とした。図 20 にはそのモデルを示した。

表 4 に計算結果と実験結果の比較を示した。ケース 1 は、計算值 が小さくなった。これはケース 1 で考慮していないせん断金物部分 の影響であり、同時に降伏するとした各部のモーメントよりも影響 大きい。すべての要素を考慮したケース 2 はすべてが降伏状態にあ ると仮定して計算しているため、過剰な結果となっている。ケース 3 は簡易計算としてもっとも精度がよいと考えられ、5\%の差にとど まった。なお、ケース 3 の計算は降伏変形の仮定が必要となるが、 前述したとおり増分解析を実施すればほぼ精度よく計算が可能であ り、ここでは簡易計算の精度を確かめる目的で実施した。

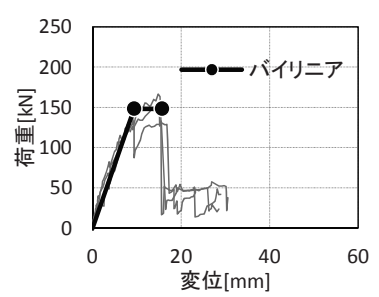

図 18 せん断金物の実験結果

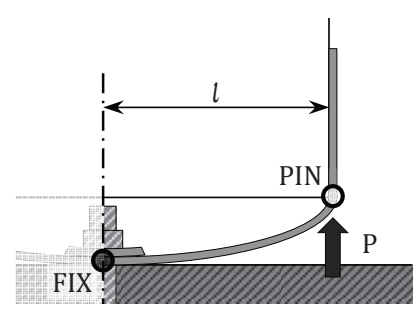

図 19 U 型金物の力学モデル

\begin{tabular}{|c|c|c|c|c|c|}
\hline ケース & $\begin{array}{c}M_{1 b} \\
{[\mathrm{kNm}]}\end{array}$ & $\begin{array}{c}M_{l h} \\
{[\mathrm{kNm}]}\end{array}$ & 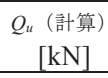 & $\begin{array}{c}Q_{u} \text { (実験) } \\
{[\mathrm{kN}]}\end{array}$ & 計算/実験 \\
\hline 1 & 169.5 & 149.9 & 139.0 & \multirow{3}{*}{167.9} & 0.828 \\
\hline 2 & 179.9 & 265.7 & 193.9 & & 1.155 \\
\hline 3 & 179.9 & 111.0 & 177.2 & & 1.055 \\
\hline
\end{tabular}

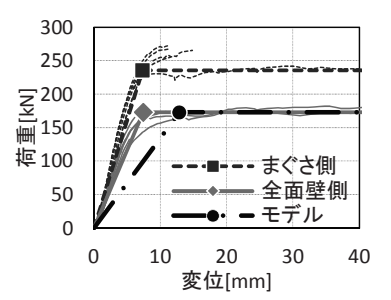

図 20 まぐさ端部の引きボルト性能

表 4 各モーメント抵抗と実験値との比較

\section{5. まとめ}

低質な木材を利用しつつも、比較的高耐力の部材として注目され ている CLT のうち、 $1 \times 3 \mathrm{~m}$ 程度の小幅パネルを引きボルトを用いて、 上下間の接合、耐力壁とまぐさなどの接合した $1 \mathrm{P}$ 耐力壁と $4 \mathrm{P}$ 構面 について水平加力実験を実施した。また、その水平加力実験の荷重 変形関係を追跡する目的で、力と変形の釣り合いに基づく式をたて て、面内部分圧縮実験、面内せん断要素実験などを併せて実施した。 以上の検討で得られた結果は以下のとおりである。

1 ） 1P 壁の水平加力実験の結果、脚部を土台などを敷かず直接基礎 に相当する部分に接合した試験体は、引きボルトの強度、勒性にそ の性能が依存寸る。今回の引きボルトを用いた壁では、70kN を超え る最大せん断耐力を示したが、脆性的な破壊性状となったものもあ った。一方で床がある想定した試験体では、木床部分で変形が進み、 比較的勒性に富んだ性状が得られた。耐力は直接基䃈上に設置され るものよりも小さな值となった。なお、CLT 壁自体は局部圧縮もみ られたが、多くは弾性域にあった。

2) $1 \mathrm{P}$ 耐力壁の荷重変形関係を鉄筋コンクリート造の単筋ばりと同 様の方法で定式化し、挙動を追跡した。計算值が小さ目であるが、 良好に剛性、強度を追跡できた。なお、1）で考察した直接基礎上 に設置される耐力壁の強度が大きくなるのは、引張力と圧縮力の合 力の距離 $j$ が大きいことにより、それがこの式からも確認できた。

3 ) 4P 構面の実験の結果、垂れ壁、腰壁の影響で、1P 耐力壁に比 べ、無開口壁の単位長さあたりの耐力の上昇が確認できた。また、 $4 \mathrm{P}$ 構面は勒性に富む構造となったが、それは、柱脚部が最大荷重を 迎えた後に荷重低下しても勒性のあるまぐさ部によってモーメント 負担があり、ピン支点のラーメンとなることによる。

4） 4P 構面の終局耐力を変形と力の釣り合いから求めた。前述した とおり柱脚部の破壊時には、まぐさのモーメントは想定した終局モ 
ーメントに対していないため、節点振り分け法をもちいると過大評 価となるが、簡易計算により $80 \%$ ～115\%程度の精度で、終局耐力 が追跡可能であった。

なお、一連の研究として、本接合システムを用いて、3 層箱型建 物に対して静加力実験 9),15)、振動台実験 ${ }^{15)}$ をでに実施しており、 その研究結果について続報として報告する予定である。

\section{謝辞}

本研究は平成 24 年度、国土交通省補助事業「木造長期優良住宅の 総合的検証委員会構造分科会」(主査：河合直人工学院大学教授）、 平成 25 26 年度国土交通省建築基準整備促進事業「S7：CLT を用い た木構造の設計法に関する検討」(委員長 : 安村基静岡大学教授)の 一環として実施した。三宅辰哉氏（日本システム設計）、荒木康弘氏 (建築研究所)、松田昌洋氏（信州大学）をはじめご助言をいただい た方々、菅沼田直人君 (当時信州大学)、志村智君、畠山太志君 (以 上、当時工学院大)、和田真美さん（京都大学）など実験に協力いた だいた関係諸氏にこの場を借りて感謝します。

\section{参考文献}

1) 直交集成板の日本農林規格、制定：平成 25 年 12 月 20 日農林水産省告示 第 3079 号

2) KLH 社のホームページｈttp://www.klhuk.com/（参照 2015.12.23）

3) Rethink Wood : CLT handbook,

http://www.rethinkwood.com//masstimber /products/（参照 2015.12.23）

4) 宮武敦、中島史郎 - 藤田和彦 - 孕石剛志 - 渋沢龍也 - 長尾博文 - 安村基 · 安藤直人: スギを用いて製造したクロス・ラミネイティド・ティンバー(CLT) の強度性能 その 1 試験の概要, 日本建築学会大会学術講演梗概集, 構造 III, pp.115-116, 2013.8

5) 大橋義徳、戸田正彦、村上了、藤田和彦、宮武敦、渋沢龍也、長尾博文、 孕石剛志、中島洋：国産材を用いたCLT の力学特性 その 1 面外曲げ性 能，日本建築学会大会学術講演梗概集，構造III，pp.313-318，2014.9

6) 後藤隆洋、鈴木圭、清水庸介、安村基、津田千尋、森清輝、三宅辰哉、槌 本敬大 : クロス・ラミネイティド・ティンバーによる構造の耐震性能に関 する研究 その 3 接合部試験, 日本建築学会大会学術講演梗概集, 構造 III, pp.309-310, 2012.9

7) 志村智、津田千尋、畠山太志、菅沼田直人、鈴木圭、岡部実、中川貴文、 荒木康弘、桘本敬大 : クロス・ラミネイティド・ティンバーによる構造の 耐震性能に関寸る研究 その 4 構面実験, 日本建築学会大会学術講演梗 概集，構造正，pp.311-312，2012.8

8) 平成 22 年度「木のまち・木のいえ整備促進事業」木造住宅・建築物等の 整備促進に関寸る技術基盤強化を行う事業、「クロス・ラミネイティド・ ティンバー構法の損傷限界に関する検討」報告書、第 3 章 壁構面水平加 力実験 http://www.nittem.co.jp/works/mokuzo choki/ pdf23/ clt23_chap03.pdf (参照 2015.12.23)

9) 平成 22 年度「木のまち・木のいえ整備促進事業」木造住宅・建築物等の 整備促進に関寸る技術基盤強化を行う事業、「クロス・ラミネイティド・ ティンバー構法の損傷限界に関する検討」報告書、第 5 章 試験体の施工 http://www.nittem.co.jp/works/mokuzo_choki/ pdf23/clt23_chap05.pdf（参照 2015.12.23)

10) 平成 26 年度 国土交通省「CLT を用いた木造建築基準の高度化推進事業」 報告書、第 6 章 水平力を受ける矩形壁パネル脚部の応力部分布確認試験 http://www.nittem.co.jp/works/kodoka/pdf26/clt26chapter06.pdf(参照 2015.12.23)

11)（財）日本住宅・木材技術センター：木造軸組工法住宅の許容応力度設計 (2008 年版), 2009.6

12) 日本建築学会：木質構造設計部マニュアル，pp.227-232，2012.4

13）鈴木圭、後藤隆洋、清水庸介、安村基、河合直人、三宅辰哉、桘本敬大、 五十田博 : クロス・ラミネイティド・ティンバーによる構造の耐震性能に 関する研究 その 20 接合部の強度と性能, 日本建築学会大会学術講演梗 概集，構造吕，pp.573-574，2013.8
14) 木構造振興株式会社：CLT パネルを用いた中高層建築物の構造計画と接 合部性能の検証事業報告書、2012.3

15) 平成 24 年度木造長期優良住宅の総合的検証事業の報告「クロス・ラミネ イティド・ティンバー構法の損傷限界・安全限界に関する検討」報告書、 http://www.nittem.co.jp/works/mokuzo_choki/h24.html（参照 2015.12.23）

\section{付録 $11 \mathrm{P}$ 壁実験・床のある試験体の脚部挙動算出の詳細}

$1 \mathrm{P}$ 壁で床のある試験体の脚部挙動について、木質構造接合部設計 マニュアルの引きボルト式柱一梁接合部 ${ }^{12)}$ に準じたその算出方法の 詳細を記す。

まず、床木口の三角変位めり込みの合力 $\Sigma N$ は付式 1)により、これ と変形角 $\theta$ の関係により、圧縮縁から中立軸までの距離 $x$ は付式 2) の 2 次方程式を解くことで求まる。また、 1 次剛性 $R_{1}$ は付式 3 より 求め、 2 次剛性 $R_{2}$ は、床のめり込み塑性変形によって生じることか ら 1 次剛性の $1 / 8$ とした。

$$
\begin{aligned}
& \Sigma N=\frac{x^{2} y C_{y} E_{\perp}}{2 Z_{0}}\left\{1+\frac{4 Z_{0}}{3 x}\left(1-e^{-\frac{3 X_{1}}{2 Z_{0}}}\right)\right\} \theta \\
& \frac{x^{2} y C_{y} E_{\perp}}{2 Z_{0}}\left\{1+\frac{4 Z_{0}}{3 x}\left(1-e^{-\frac{3 x_{1}}{2 Z_{0}}}\right)\right\} \frac{1}{k}=d-x \\
& R_{1}=\frac{x^{2} y C_{y} E_{\perp}}{2 Z_{0}}\left(C_{x} \cdot d-\frac{x_{p}}{3}\right)
\end{aligned}
$$

さらに脚部の曲げモーメントは圧縮側でめり込み降伏が生じた後 に、引きボルトが終局に至ると考え、付式 4)、5)により求められる。

$$
\begin{aligned}
& M_{y}=\Sigma N_{y}\left(d-\frac{1}{3} \cdot \frac{x}{C_{x}}\right) \\
& M_{u}=T\left(d-\frac{1}{3} \cdot \frac{x}{C_{x}}\right) \\
& M_{y}: \text { 降伏モーメント、 } M_{u}: \text { 終局モーメント }
\end{aligned}
$$

めり込み降伏に至るときの合力 $\Sigma N_{y}$ は付式 6)により求まる降伏回 転角 $\theta_{y}$ を代入し、式 7)により求まる。

$$
\begin{aligned}
& \theta_{y}=\frac{Z_{0} F_{m}}{x E_{\perp} \sqrt{C_{x} C_{y} C_{x m} C_{y m}}} \\
& \sum N_{y}=\frac{x y F_{m}}{2} \sqrt{\frac{C_{x} C_{y}}{C_{x m} C_{y m}}}
\end{aligned}
$$

$F_{m}$ : 縁距離を無限大にした時のめり込み降伏度（めり込み強 度 $F_{c v}$ に 0.8 を乗じたものとした。)

式中のCはいわゆる形状係数であり、付式 8)〜11)に整理する。

$$
\begin{aligned}
& C_{x}=1+\frac{4 Z_{0}}{3 x}\left(1-e^{-\frac{3 x_{1}}{2 Z_{0}}}\right) \\
& C_{y}=1+\frac{4 Z_{0}}{3 n b}\left(1-e^{-\frac{3 y_{1}}{2 Z_{0}}}\right) \\
& C_{x m}=1+\frac{4 Z_{0}}{3 x} \\
& C_{y m}=1+\frac{4 Z_{0}}{3 n b}
\end{aligned}
$$

$Z_{0}$ : 床 CLT の高さ、 $x_{1}$ : CLT 壁面から床縁までの面内距離、 $y_{1}:$ CLT 壁面から床縁までの面外距離、 $n$ : 繊維方向に対す る繊維直交方向の置換係数 


\title{
LATERAL STRUCTURAL PERFORMANCE OF NARROW SIZE CROSS LAMINATED TIMBER CONNECTED WITH TENSILE BOLTS
}

\author{
Sota MIURA*, Hirosi ISODA**, Takahiro TSUCHIMOTO***, \\ Takahumi NAKAGAWA***, Akihisa KITAMORI*****, Kei SUZUKI****** \\ and Chihiro TSUDA $* * * * * * *$ \\ * Grad. Stud., Graduate School of Engineering, Shinshu Univ. \\ ** Prof., RISH, Kyoto Univ./ Visiting Researcher, BRI, Dr.Eng. \\ *** Chief Research Eng., Dept. of Building Materials and Components, Building Research Institute, Dr.Agr. \\ $* * * *$ Senior Researcher, Building Dept., NILIM, MLIT, Dr.Agr. \\ ***** Assist. Prof., Research Institute for Sustainable Humanosphere, Kyoto Univ., Dr.Agr. \\ ****** Chief Researcher, Wood Structure Prom/ The University of Tokyo, M.Agr. \\ $* * * * * * *$ Structural Engineer, Team Architect Office, Dr.Eng.
}

Though the Japanese domestic forests planted after 1945, have grown up enough to use as building components or elements of composite material, they have never used enough to plant the next generation and been maintained enough. So, it is a great fear that the multiple functions of the forest such as watershed conservation, the land conservation, and so on have been declined. Under these situations, The Act for Promotion of Use of Wood in Public Buildings was established and enacted October 2010. On the other hand, the construction employing the cross laminates timber (CLT) panels was offered as a method of large scale building in domestic and foreign countries. However, the seismic design method of CLT panel construction has never completed. So, in order to consider the seismic design method, shear wall tests of single wall $(1 \mathrm{x} 3 \mathrm{~m})$ were conducted to evaluate the shear performance such as stiffness, strength and ductility. And then $4 \mathrm{~m}$ width walls consisting of double 1x3m of CLT panel shear walls and hanging panel were also conducted. Tensile bolts were used as connection between shear wall and foundation, shear wall and hanging wall, and top-bottom joint of shear wall. Simple tensile tests for every bolt joint, compression, shear and bending tests for CLT panel were conducted to calculate the load-displacement relationship and to make structural design procedure of the shear wall. As results of these static loading tests are summarized as follows:

1) The strength and ductility of single shear wall on the foundation produced from tensile bolt joint. These performance of shear walls on the foundation connected with hanging wall also depend on the performance of tensile bolt joints. The first yield was occurred at the compression area of CLT floor for the shear wall on the CLT floor and the strength of the shear wall also was determined by the strength of tensile bolt. Each CLT panel remains elastic behavior and contribution of shear deformation produced from elastic deformation of CLT compression shear and bending is much less than the deformation of connections. It means that the key issue of seismic performance of CLT construction is a design approach of connection.

2) Equations to calculate load-displacement relationship of single shear wall from the performance of the tensile bolt joint and partial compression of CLT edge, shear and bending deformation of CLT are defined from the equilibrium of internal force and external force. Based on the comparison between parameters from equations and experimental results, these equations are confirmed as a structural design. The maximum shear load of double shear walls and hanging wall is estimated from the principle of virtual work agree method with the test results 